\title{
A multicentre phase II trial of cabazitaxel in patients with advanced non-small-cell lung cancer progressing after docetaxel-based chemotherapy
}

\author{
A Kotsakis ${ }^{*}{ }^{1}$, A Matikas ${ }^{1}$, F Koinis ${ }^{1}$, N Kentepozidis ${ }^{1}$, I I Varthalitis ${ }^{1}$, V Karavassilis ${ }^{1}$, Ep Samantas ${ }^{1}$, \\ P Katsaounis ${ }^{1}$, E K Dermitzaki ${ }^{1}$, D Hatzidaki ${ }^{1}$, D Mavroudis ${ }^{1}$ and V Georgoulias ${ }^{1}$ \\ ${ }^{1}$ Hellenic Oncology Research Group (HORG), 55 Lombardou Street, Athens 11470, Greece
}

\begin{abstract}
Background: Cabazitaxel, a semisynthetic microtubule inhibitor, has shown antitumour activity in models resistant to paclitaxel and docetaxel, and it has been approved for the treatment of docetaxel-resistant prostate cancer. We investigated its activity in patients with advanced non-small-cell lung cancer (NSCLC) progressing under or after docetaxel-based regimens.
\end{abstract}

\begin{abstract}
Methods: Patients with locally advanced unresectable or metastatic NSCLC, with an Eastern Cooperative Oncology Group performance status of $0-2$, were enrolled; patients had to have received up to two prior chemotherapy regimens for the treatment of advanced disease, including one docetaxel-containing regimen. Treatment consisted of cabazitaxel $\left(25 \mathrm{mg} \mathrm{m}^{-2}\right.$ intravenously, every 21 days) until disease progression. The primary end point was the overall response rate.
\end{abstract}

Results: Among the 46 evaluable patients, $28.3 \%$ had squamous cell carcinoma and $54.3 \%$ had adenocarcinoma. Eight (17.4\%) patients had received one and $38(82.6 \%)$ two prior chemotherapy regimens. Treatment compliance was $95 \% ; 26(16 \%)$ cycles were delayed because of toxicity, $(n=13)$ and dose reduction was required in $6(13 \%)$ patients because of haematologic toxicity. Six (13\%) patients achieved a partial response and $17(37.0 \%)$ stable disease. The median progression-free survival and overall survival were $2.1(95 \%$ confidence interval (Cl): 1.0-3.2) and 7.4 (95\% Cl: 5.2-9.6) months, respectively. Grade 4 adverse events included neutropenia $(n=8 ; 17 \%)$, febrile neutropenia $(n=6 ; 13 \%)$ and thrombocytopenia $(n=3 ; 6.5 \%)$. There was one treatment-related death.

Conclusions: Cabazitaxel exhibits activity in NSCLC patients pre-treated with docetaxel-based chemotherapy with a substantial but manageable toxicity profile. The drug merits further evaluation in this indication.

Lung cancer is the leading cause of cancer-related deaths in men and women (Siegel et al, 2015). Approximately half of the patients with newly diagnosed non-small-cell lung cancer (NSCLC) present with metastatic disease, which confers a particularly poor prognosis. The median overall survival (OS) is $\sim 10$ months and the 5 -year survival rate is $<1 \%$ (Groome et al, 2007). These facts clearly underscore the need for more effective treatments for this highly lethal disease. The identification of several driver mutations, the recognition of the phenomenon of 'tumour addiction' to these mutations and the development of potent targeted agents has offered new treatment options for a small number of patients (Mok et al, 2009; Rosell et al, 2012; Shaw et al, 2014; Solomon et al, 2014; Yang et al, 2015). However, for the majority of patients, palliative cytotoxic chemotherapy is the only treatment option as it offers symptoms control and a modest prolongation of survival.

Recent advances with the immune checkpoint inhibitors as well as new antiangiogenic agents, such as ramucirumab and

*Correspondence: Dr A Kotsakis; E-mail: kotsakis@med.uoc.gr

Received 1 April 2016; revised 3 August 2016; accepted 14 August 2016; published online 8 September 2016

(c) 2016 Cancer Research UK. All rights reserved 0007 - 0920/16 
nintedanib, for patients with advanced NSCLC have led to their approval for use after first-line treatment failure by the Food and Drug Administration and the European Medicines Agency. This improvement in survival among patients with metastatic NSCLC results in an increase of the number of patients requiring further treatment. Consequently, clinical practice guidelines support the use of monochemotherapy for these patients, based on the results of a meta-analysis of six trials (Di Maio et al, 2009).

Taxanes have demonstrated significant activity in randomised trials in both first- and second-line settings of advanced NSCLC (Fossella et al, 2000, 2003; Shepherd et al, 2000). Cabazitaxel (Jevtana; SanofiAventis, Paris, France) is a semisynthetic taxane that acts by binding to tubulin and inhibiting microtubule depolymerisation and cell division, thus resulting in cell cycle arrest. Cabazitaxel was selected for clinical testing owing to its poor affinity for the drug efflux pump P-gp1, its greater blood-brain barrier penetration compared with other taxanes and its superior activity in vitro against human cancer cell lines compared with docetaxel (Cisternino et al, 2003; Mita et al, 2009). Interestingly, cabazitaxel has also been shown to be active in cancer cell lines with innate or acquired resistance to docetaxel (Vrignaud et al, 2013). The activity of cabazitaxel in docetaxelresistant tumours has been demonstrated to be clinically relevant in the phase III TROPIC trial, where treatment with cabazitaxel was shown to improve OS compared with mitoxantrone in patients with metastatic castration-resistant prostate cancer previously treated with docetaxel (de Bono et al, 2010).

The limited efficacy associated with currently available treatments for NSCLC, in second- or third-line setting, highlights the need to develop new agents to treat these patients. Considering the significant activity of cabazitaxel in pre-treated patients with prostate cancer, we evaluated its activity and tolerability in a pivotal phase II trial in NSCLC patients with advanced, unresectable or metastatic disease previously treated with docetaxel-based chemotherapy.

\section{MATERIALS AND METHODS}

Study design. This single-arm, multicentre investigator-initiated phase II study aimed to examine the role of cabazitaxel in advanced NSCLC patients pre-treated with docetaxel, and was conducted at six collaborative centres of the Hellenic Oncology Research Group (HORG). The protocol was approved by the institutional review boards of the participating centres, the independent National Ethics Committee and the Greek Medicinal Agency (EOF) and registered under the NCT01852578 identifier at the Clinicaltrials.Gov website. The study was conducted in compliance with Good Clinical Practice in the Declaration of Helsinki. Written informed consent was obtained from all patients before enrolment. The study was funded by the HORG and the Cretan Association for Biomedical research (CABR). The investigational drug was provided free of charge by Sanofi-Aventis.

Patients. Patients with histologically or cytologically confirmed advanced unresectable or metastatic NSCLC and an Eastern Cooperative Oncology Group performance status (ECOG PS) of $0-2$ were eligible for this study. Additional key eligibility criteria included up to two prior chemotherapy lines, including one docetaxel-containing regimen; at least one measurable lesion that was not previously irradiated, according to the Response Evaluation Criteria In Solid Tumours (RECIST) version 1.1; adequate marrow, renal and liver function; and a life expectancy of at least 3 months. Patients with previously irradiated and clinically stable brain metastases were allowed to enroll.

Treatment plan. Patients enrolled in the study received treatment with cabazitaxel $25 \mathrm{~m} / \mathrm{m}^{-2}$ of body surface area, given by intravenous infusion over $1 \mathrm{~h}$ on day 1 of each 21-day cycle. Premedication consisting of single intravenous doses of an antihistamine, corticosteroid and histamine $\mathrm{H} 2$ antagonist were also administered $30 \mathrm{~min}$ or more before the administration of cabazitaxel. Treatment was administered until disease progression, unacceptable toxicity or patient refusal. In cases of grade 3 or 4 of predefined haematologic or non-haematologic toxicity, the dose of cabazitaxel was reduced at $20 \mathrm{mg} \mathrm{m}^{-2}$. Only one dose reduction was allowed per patient. If a second dose reduction was required, the patient was withdrawn from the study. Primary prophylaxis with filgrastim or pegfilgrastim was administered according to the treating physician's discretion.

Pre-treatment evaluation included a complete medical history, physical examination and blood pressure measurement; a complete blood count $(\mathrm{CBC})$ with differential and platelet count; standard biochemical profile; electrocardiogram (ECG); chest X-rays; computed tomography scans of the chest, abdomen and brain, as well as bone scintigraphy. During treatment, a CBC count was performed weekly. A detailed medical history was taken and complete physical examination was performed before the administration of each course of treatment to document symptoms of disease and chemotherapy-related toxicities. Biochemical tests, blood measurement, ECG and chest X-rays were performed every 3 weeks. Lesions assessable by ultrasound and/or computed tomography scans were evaluated after every two courses of treatment.

Clinical outcomes. The primary end point of the study was the overall response rate (ORR), defined as the proportion of patients with complete or partial response (PR) according to the RECIST criteria, version 1.1. The secondary end points were: (i) disease control rate (DCR), defined as the proportion of patients with complete response, PR and stable disease (SD); (ii) progression-free survival (PFS), defined as the time interval between the date of enrolment and the date of disease progression or death by any cause; (iii) OS, defined as the time interval between the date of enrolment and the date of death; and (iv) the safety profile and the adverse events of the regimen, according to the NCI-Common Terminology Criteria for adverse events (CTCAE version 4.0).

Statistical considerations. Given that the objective response rate with active agents in randomised phase III trials in the second-line setting of NSCLC is $\sim 7-10 \%$, an objective response rate of $7.5 \%$ was required to consider that the drug is potentially active in this setting and deserves further evaluation. The sample size calculation was conducted according to Simon's two-step design (Minmax design) testing the hypothesis of a very low or no response rate $(0.05 \%)$ against the alternative of a response rate of at least $7.5 \%$; according to the test an interim analysis was planned to take place on the first 25 patients, and if there was one response observed, then the study would continue with 21 additional patients for a total number of 46 enrolments. An ORR $\geqslant 7.5 \%$ would be considered adequately efficient for further study of the drug with a type I error of 0.05 and a power of $80 \%$.

Analysis was performed on an intent-to-treat basis and all patients who received at least one cycle of treatment were included. Summary tables (descriptive statistics and/or frequency tables) are provided for all baseline and efficacy variables, as appropriate. Continuous variables are summarised with descriptive statistics $(n$, median, range). Ninety-five per cent confidence intervals (95\% CI) are also presented, as appropriate. Overall survival and PFS for all patients were estimated using the Kaplan-Meier method.

All clinical data were held centrally (Clinical Trial Office, HORG) and analys using the SPSS statistical software, version 22.0 (SPSS Inc., Chicago, IL, USA).

\section{RESULTS}

Patient characteristics. From September 2012 to December 2013, a total of 46 patients were enrolled in the study. The patients' 
median age was 64 years (range, 37-81 years) and $41(89.1 \%)$ of them were men; all had an ECOG PS of $0-1$ and $44(95.7 \%)$ of them had stage IV disease. Histology was squamous cell in 13 $(28.3 \%)$ patients, adenocarcinoma in 25 (54.3\%), large cell carcinoma in $1(2.2 \%)$ and undifferentiated NSCLC (15.2\%) in 7. Among treated patients, eight (17.4\%) received cabazitaxel at the second-line setting and $38(82.6 \%)$ at the third-line setting. Twenty-four patients (52.2\%) received docetaxel as first-line treatment and $22(47.8 \%)$ as second-line treatment. The median time from the previous docetaxel-based regimen was 3.2 months; 21 patients had docetaxel-refractory disease and 22 patients had acquired resistance to docetaxel. None of the enrolled patients harbored EGFR mutation or EML4-ALK rearrangement. Patients' demographic and clinical data are summarised in Table 1.

Drug exposure and compliance with treatment. A total of 165 chemotherapy cycles were administered, with a median of three cycles per patient (range, 1-13). Twenty-six cycles (15.6\%) were delayed owing to haematologic $(n=3)$, non-haematologic $(n=7)$ and both haematologic and non-haematologic toxicity $(n=3)$ and 13 owing to other reasons, mainly logistics (late admission to the chemotherapy unit) and patient preference. Dose reduction was required in six patients because of haematologic $(n=3)$, non-haematologic $(n=2)$ and both haematologic and non-haematologic $(n=1)$ toxicity. At the time of data cutoff and analysis, 45 patients (97.8\%) had discontinued treatment, most commonly because of disease progression. The mean dose intensity of cabazitaxel was $91.2 \%$.

Treatment activity. During the initial stage of the trial, five PRs were observed and enrolment was continued. There were no complete responders; in the intention-to-treat population $(n=46)$, six patients achieved a PR (ORR = 13.0\%; 95\% CI: 3.3-22.8\%), 17 had SD and 20 experienced disease progression (PD); the DCR was $49.9 \%$ (95\% CI: $35.6 \%-64.4 \%)$. There was no difference between patients treated at

Table 1. Patient clinical and demographic data

\begin{tabular}{|c|c|c|}
\hline & $N=46$ & $\%$ \\
\hline Age (years), median (min-max) & \multicolumn{2}{|c|}{64 (37-81) } \\
\hline $\begin{array}{l}\text { Sex } \\
\text { Male } \\
\text { Female }\end{array}$ & $\begin{array}{r}41 \\
5\end{array}$ & $\begin{array}{l}89.1 \\
10.9\end{array}$ \\
\hline $\begin{array}{l}\text { Performance status } \\
0 \\
1\end{array}$ & $\begin{array}{l}23 \\
23\end{array}$ & $\begin{array}{l}50.0 \\
50.0\end{array}$ \\
\hline $\begin{array}{l}\text { Stage } \\
\text { IIIB } \\
\text { IV }\end{array}$ & $\begin{array}{r}2 \\
44\end{array}$ & $\begin{array}{r}4.3 \\
95.7\end{array}$ \\
\hline $\begin{array}{l}\text { Histology } \\
\text { Squamous } \\
\text { Adenocarcinoma } \\
\text { Large cell } \\
\text { Undifferentiated }\end{array}$ & $\begin{array}{r}13 \\
25 \\
1 \\
7\end{array}$ & $\begin{array}{c}28.3 \\
54.3 \\
2.2 \\
15.2\end{array}$ \\
\hline $\begin{array}{l}\text { Smoking status } \\
\text { Non-smoker } \\
\text { Former smoker } \\
\text { Active smoker }\end{array}$ & $\begin{array}{r}5 \\
24 \\
17\end{array}$ & $\begin{array}{l}10.9 \\
52.2 \\
37.0\end{array}$ \\
\hline Baseline brain metastases & 7 & 15.2 \\
\hline Prior surgery & 10 & 21.7 \\
\hline Prior definitive radiation & 13 & 28.3 \\
\hline Prior palliative radiation & 6 & 13.0 \\
\hline $\begin{array}{l}\text { Line therapy } \\
\text { Second line } \\
\text { Third line }\end{array}$ & $\begin{array}{r}8 \\
38\end{array}$ & $\begin{array}{l}17.4 \\
82.6\end{array}$ \\
\hline $\begin{array}{l}\text { Line received docetaxel } \\
\text { First line } \\
\text { Second line }\end{array}$ & $\begin{array}{l}24 \\
22\end{array}$ & $\begin{array}{l}52.2 \\
47.8\end{array}$ \\
\hline
\end{tabular}

the second line $(n=8, \mathrm{DCR} 37.5 \%$, PR $25 \%)$ and third line $(n=38$, DCR $52.6 \%$, PR 10.5\%). In addition, among patients with primary refractory disease, the $\mathrm{PR}$ and $\mathrm{SD}$ rates were $4.3 \%$ and $26.1 \%$, respectively. Among patients with acquired resistance to docetaxel, $21.7 \%$ experienced a PR and $47.8 \%$ had disease stabilisation. The median duration of response was 2.9 months. After a median followup period of 11.9 months (range, 0.8-15.2 months), median PFS was 2.1 months (95\% CI: 1.0-3.2 months) (Figure 1). At the time of data analysis, 32 patients had died; the median OS was 7.4 months $(95 \%$ CI: 5.2-9.6 months) (Figure 2). The 6- and 12-month survival estimates were $61.2 \%$ and $20.3 \%$, respectively.

Safety. Treatment-related adverse events are summarised in Table 2. There was one toxic death, attributed to febrile neutropenia, grade 4 thrombocytopenia and respiratory infection. The most common adverse events were anaemia (all grades, $82.7 \%$; grades $3-4,8.7 \%$ ), lymphopenia (all grades, 69.6\%; grades $3-4,28.3 \%$ ) and fatigue (all grades, 52.1\%; grade 3, 4.3\%). Grade 3-4 neutropenia occurred in $32.6 \%$ of patients and grade 3-4 thrombocytopenia in $6.5 \%$. There were six episodes of febrile neutropenia (13.0\%), and $69 \%$ of the patients received at least one dose of granulocyte colony-stimulating factor (G-CSF).One patient presented with paralytic ileus and another with haemorrhagic cystitis; both were deemed related to the study treatment and both resolved with conservative measures.

\section{DISCUSSION}

We report the results of a multicentre, single-arm phase II trial that evaluated the activity of cabazitaxel in patients with advanced NSCLC who had previously received docetaxel. To our knowledge, this is the first trial evaluating cabazitaxel in patients with NSCLC. The study clearly demonstrates that cabazitaxel displayed considerable activity in relatively heavily pre-treated patients, as over $80 \%$ of the enrolled patients had received two prior chemotherapy lines. Indeed, the ORR of $13.0 \%$ is approximately double to that achieved by second-line docetaxel in multiple phase III trials (Fossella et al, 2000, 2003; Hanna et al, 2004; Garassino et al, 2013). In addition, a DCR of $50 \%$ is comparable with results observed in trials in the second-line setting.

One limitation of our study is the relatively low number of patients $(n=46)$ and the absence of a comparator arm. As such, comparison of efficacy end points achieved with other regimens may be highly biased by patient selection. This is more important as the majority of patients enrolled in the study received cabazitaxel as third-line treatment. The only trial that has shown improved survival at the third line is the BR.21 trial, in which erlotinib was compared with placebo (Shepherd et al, 2005). However, despite the absence of randomised trials of chemotherapy vs BSC at the third-line setting of

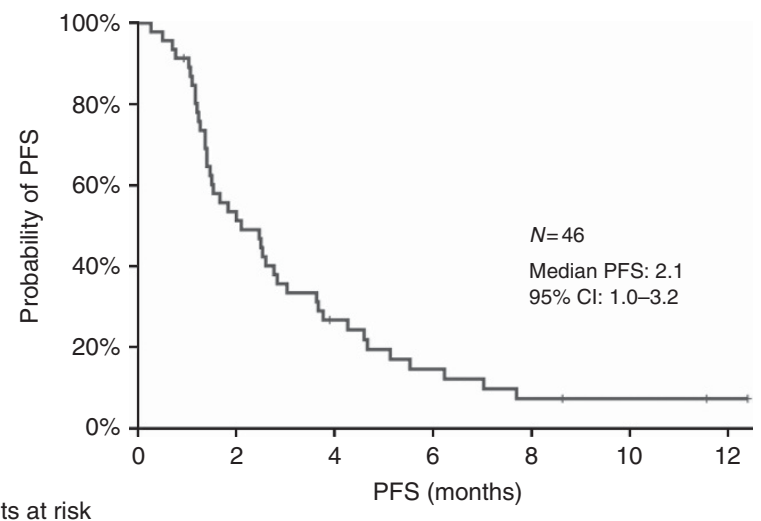

No. of pts at risk

Cabazitaxel 46 23 11 3 2

Figure 1. Kaplan-Meier curve for progression-free survival. 
advanced NSCLC, guidelines issued by the National Comprehensive Cancer Network (NCCN Clinical Practice Guidelines in Oncology, 2016) support the use of monochemotherapy in selected patients after two disease progressions. Therefore, in the absence of a comparator arm including patients receiving BSC, it is difficult to draw definite conclusions. Additionally, although enrolment of patients with PS 2 was allowed in the trial, no such patient was actually enrolled; as heavily pre-treated patients with advanced NSCLC commonly experience a deterioration of their PS, our results can only be applied on selected patients with a good PS.

Recently, in three phase III trials, immune checkpoint inhibition with programmed death protein-1 blockade using the monoclonal

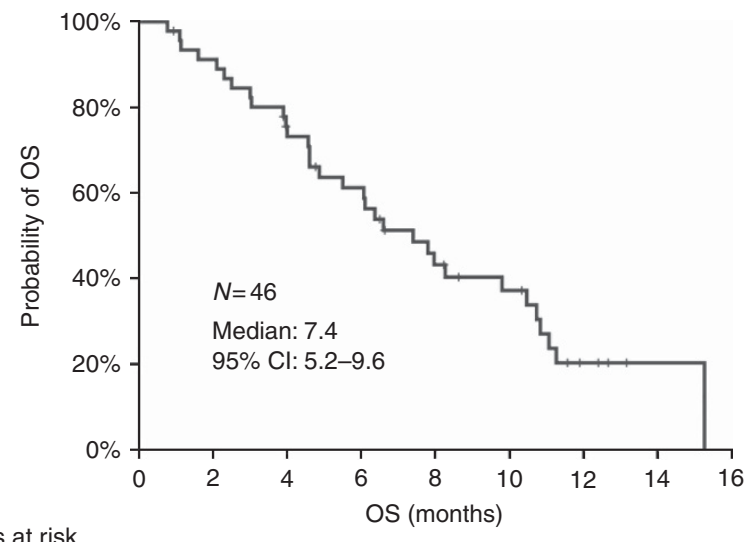

No. of pts at risk

\begin{tabular}{llllllllll}
\hline Cabazitaxel & 46 & 41 & 31 & 25 & 16 & 12 & 4 & 1 & 0
\end{tabular}

Figure 2. Kaplan-Meier curve for overall survival.

Table 2. Summary of treatment-related adverse events

\begin{tabular}{|c|c|c|c|c|c|c|}
\hline & \multicolumn{2}{|c|}{ Grades 1 and 2} & \multicolumn{2}{|c|}{ Grade 3} & \multicolumn{2}{|c|}{ Grade 4} \\
\hline & $N$ & $\%$ & $N$ & $\%$ & $N$ & $\%$ \\
\hline Leukopenia & 8 & 17.4 & 4 & 8.7 & 6 & 13.0 \\
\hline Neutropenia & 6 & 13 & 7 & 15.2 & 8 & 17.4 \\
\hline Lymphopenia & 19 & 41.3 & 12 & 26.1 & 1 & 2.2 \\
\hline Febrile neutropenia & - & - & - & - & 6 & 13.0 \\
\hline Anaemia & 34 & 74 & 4 & 8.7 & - & - \\
\hline Thrombocytopenia & 4 & 8.7 & - & - & 3 & 6.5 \\
\hline Nausea & 3 & 6.5 & - & - & - & - \\
\hline Vomiting & 6 & 13 & 1 & 2.2 & - & - \\
\hline Diarrhoea & 5 & 10.8 & 2 & 4.3 & - & - \\
\hline Mucositis & 3 & 6.5 & - & - & - & - \\
\hline Constipation & 2 & 4.4 & - & - & - & - \\
\hline Neurotoxicity & 5 & 10.9 & - & - & - & - \\
\hline Skin toxicity & 4 & 8.7 & - & - & - & - \\
\hline Allergy & 1 & 2.2 & - & - & - & - \\
\hline Infection & 7 & 15.2 & 3 & 6.5 & - & - \\
\hline Fever & 10 & 21.8 & - & - & - & - \\
\hline Fatigue & 22 & 47.8 & 2 & 4.3 & - & - \\
\hline Oedema & 1 & 2.2 & - & - & - & - \\
\hline $\begin{array}{l}\text { Transaminase } \\
\text { elevation }\end{array}$ & 6 & 13 & - & - & - & - \\
\hline Dyspnoea & 18 & 39.1 & 1 & 2.2 & - & - \\
\hline Nephrotoxicity & 3 & 6.5 & - & - & - & - \\
\hline Headache & 2 & 4.4 & - & - & - & - \\
\hline
\end{tabular}

antibodies nivolumab and pembrolizumab was shown to clearly improve median OS compared with second-line docetaxel in patients with advanced NSCLC (Borghaei et al, 2015; Brahmer et al, 2015; Herbst et al, 2015). In addition, the combinations of the angiogenesis inhibitor ramucirumab with docetaxel and the tyrosine kinase inhibitor nintedanib with docetaxel had also resulted in improved survival compared with docetaxel monotherapy (Garon et al, 2014; Reck et al, 2014). This change of paradigm is reflected in contemporary practice guidelines.

Despite an abundance of options for the pre-treated NSCLC population, single-agent chemotherapy still has an important place in the management of patients requiring further treatment. In the two nivolumab trials, CheckMate 017 and CheckMate 057, 40\% of patients who progressed on nivolumab received chemotherapy, with the most common option being docetaxel (Shepherd et al, 2005).Importantly, only a minority of patients derive benefit from immunotherapy; the development of effective agents for these patients is an unmet need. Moreover, it has been demonstrated in prospective trials that there is a lack of cross-resistance between the taxanes, especially for docetaxel after paclitaxel in advanced NSCLC (Fossella et al, 2000) and for cabazitaxel after docetaxel in castration-resistant prostate cancer (de Bono et al, 2010).

Treatment with cabazitaxel was relatively well tolerated. The majority of adverse events were mild; however, there was one case of paralytic ileus, one case of haemorrhagic cystitis and one case of toxic death. The incidence of severe, grade 3-4 neutropenia and neutropenic fever were less common compared with the rates reported in the TROPIC trial in prostate cancer (de Bono et al, 2010). In addition, the incidence of neutropenia was lower compared with the reported rates in a phase III trial of docetaxel in the second-line treatment of NSCLC (Fossella et al, 2003), probably attributed to the frequent use of optional primary prophylaxis with G-CSF in our trial.

In conclusion, the study met its primary objective as the ORR of $13 \%$ compares favorably with published trials on pre-treated advanced NSCLC. Furthermore, treatment with cabazitaxel was tolerated with manageable toxicity, despite the majority of the patients received the drug as third-line treatment. Owing to its encouraging activity, further evaluation of cabazitaxel is warranted, especially in the light of the newer treatment options that tend to replace chemotherapy in the second-line setting.

\section{ACKNOWLEDGEMENTS}

This work was partially supported by the Cretan Association for Biomedical Research (CABR). We acknowledge the assistance of the scientific secretary Vasso Athanasaki in the preparation of this manuscript. This trial was funded in part by the Hellenic Oncology Research Group (HORG). The study drug was supplied by Sanofi Aventis.

\section{CONFLICT OF INTEREST}

All the authors have no relevant financial interests. The authors declare no conflict of interest.

\section{REFERENCES}

Borghaei H, Paz-Ares L, Horn L, Spigel DR, Steins M, Ready NE, Chow LQ, Vokes EE, Felip E, Holgado E, Barlesi F, Kohlhaufl M, Arrieta O, Burgio MA, Fayette J, Lena H, Poddubskaya E, Gerber DE, Gettinger SN, Rudin CM, Rizvi N, Crino L, Blumenschein Jr. GR, Antonia SJ, Dorange C, Harbison CT, Graf Finckenstein F, Brahmer JR (2015) Nivolumab versus docetaxel in advanced nonsquamous non-small-cell lung cancer. $N$ Engl J Med 373: $1627-1639$. 
Brahmer J, Reckamp KL, Baas P, Crino L, Eberhardt WE, Poddubskaya E, Antonia S, Pluzanski A, Vokes EE, Holgado E, Waterhouse D, Ready N, Gainor J, Aren Frontera O, Havel L, Steins M, Garassino MC, Aerts JG, Domine M, Paz-Ares L, Reck M, Baudelet C, Harbison CT, Lestini B, Spigel DR (2015) Nivolumab versus docetaxel in advanced squamous-cell non-small-cell lung cancer. $N$ Engl J Med 373: 123-135.

Cisternino S, Bourasset F, Archimbaud Y, Semiond D, Sanderink G, Scherrmann JM (2003) Nonlinear accumulation in the brain of the new taxoid TXD258 following saturation of P-glycoprotein at the blood-brain barrier in mice and rats. Br J Pharmacol 138: 1367-1375.

de Bono JS, Oudard S, Ozguroglu M, Hansen S, Machiels JP, Kocak I, Gravis G, Bodrogi I, Mackenzie MJ, Shen L, Roessner M, Gupta S, Sartor AO (2010) Prednisone plus cabazitaxel or mitoxantrone for metastatic castrationresistant prostate cancer progressing after docetaxel treatment: a randomised open-label trial. Lancet 376: 1147-1154.

Di Maio M, Chiodini P, Georgoulias V, Hatzidaki D, Takeda K, Wachters FM, Gebbia V, Smit EF, Morabito A, Gallo C, Perrone F, Gridelli C (2009) Meta-analysis of single-agent chemotherapy compared with combination chemotherapy as second-line treatment of advanced non-small-cell lung cancer. J Clin Oncol 27: 1836-1843.

Fossella F, Pereira JR, von Pawel J, Pluzanska A, Gorbounova V, Kaukel E, Mattson KV, Ramlau R, Szczesna A, Fidias P, Millward M, Belani CP (2003) Randomized, multinational, phase III study of docetaxel plus platinum combinations versus vinorelbine plus cisplatin for advanced non-small-cell lung cancer: the TAX 326 study group. J Clin Oncol 21: 3016-3024.

Fossella FV, DeVore R, Kerr RN, Crawford J, Natale RR, Dunphy F, Kalman L, Miller V, Lee JS, Moore M, Gandara D, Karp D, Vokes E, Kris M, Kim Y, Gamza F, Hammershaimb L (2000) Randomized phase III trial of docetaxel versus vinorelbine or ifosfamide in patients with advanced nonsmall-cell lung cancer previously treated with platinum-containing chemotherapy regimens. The TAX 320 Non-Small Cell Lung Cancer Study Group. J Clin Oncol 18: 2354-2362.

Garassino MC, Martelli O, Broggini M, Farina G, Veronese S, Rulli E, Bianchi F, Bettini A, Longo F, Moscetti L, Tomirotti M, Marabese M, Ganzinelli M, Lauricella C, Labianca R, Floriani I, Giaccone G, Torri V, Scanni A, Marsoni S (2013) Erlotinib versus docetaxel as second-line treatment of patients with advanced non-small-cell lung cancer and wild-type EGFR tumours (TAILOR): a randomised controlled trial. Lancet Oncol 14: 981-988.

Garon EB, Ciuleanu TE, Arrieta O, Prabhash K, Syrigos KN, Goksel T, Park K, Gorbunova V, Kowalyszyn RD, Pikiel J, Czyzewicz G, Orlov SV, Lewanski CR, Thomas M, Bidoli P, Dakhil S, Gans S, Kim JH, Grigorescu A, Karaseva N, Reck M, Cappuzzo F, Alexandris E, Sashegyi A, Yurasov S, Perol M (2014) Ramucirumab plus docetaxel versus placebo plus docetaxel for second-line treatment of stage IV non-small-cell lung cancer after disease progression on platinum-based therapy (REVEL): a multicentre, doubleblind, randomised phase 3 trial. Lancet 384: 665-673.

Groome PA, Bolejack V, Crowley JJ, Kennedy C, Krasnik M, Sobin LH, Goldstraw P (2007) The IASLC Lung Cancer Staging Project: validation of the proposals for revision of the $\mathrm{T}, \mathrm{N}$, and $\mathrm{M}$ descriptors and consequent stage groupings in the forthcoming (seventh) edition of the TNM classification of malignant tumours. $J$ Thorac Oncol 2: 694-705.

Hanna N, Shepherd FA, Fossella FV, Pereira JR, De Marinis F, von Pawel J, Gatzemeier U, Tsao TC, Pless M, Muller T, Lim HL, Desch C, Szondy K, Gervais R, Shaharyar, Manegold C, Paul S, Paoletti P, Einhorn L, Bunn Jr. PA (2004) Randomized phase III trial of pemetrexed versus docetaxel in patients with non-small-cell lung cancer previously treated with chemotherapy. J Clin Oncol 22: 1589-1597.

Herbst RS, Baas P, Kim DW, Felip E, Perez-Gracia JL, Han JY, Molina J, Kim JH, Arvis CD, Ahn MJ, Majem M, Fidler MJ, de Castro Jr G, Garrido M, Lubiniecki GM, Shentu Y, Im E, Dolled-Filhart M, Garon EB (2015) Pembrolizumab versus docetaxel for previously treated, PD-L1positive, advanced non-small-cell lung cancer (KEYNOTE-010): a randomised controlled trial. Lancet 387: 1540-1550.

Mita AC, Denis LJ, Rowinsky EK, Debono JS, Goetz AD, Ochoa L, Forouzesh B, Beeram M, Patnaik A, Molpus K, Semiond D, Besenval M, Tolcher AW (2009) Phase I and pharmacokinetic study of XRP6258 (RPR 116258A), a novel taxane, administered as a 1-hour infusion every 3 weeks in patients with advanced solid tumors. Clin Cancer Res 15: 723-730.
Mok TS, Wu YL, Thongprasert S, Yang CH, Chu DT, Saijo N, Sunpaweravong P, Han B, Margono B, Ichinose Y, Nishiwaki Y, Ohe Y, Yang JJ, Chewaskulyong B, Jiang H, Duffield EL, Watkins CL, Armour AA, Fukuoka M (2009) Gefitinib or carboplatin-paclitaxel in pulmonary adenocarcinoma. N Engl J Med 361: 947-957.

NCCN Clinical Practice Guidelines in Oncology (2016) Non-small cell lung cancer version 4.2016. Available at: http://www.nccn.org/professionals/ physician_gls/pdf/nscl.pdf (last accessed 18 January 2016).

Reck M, Kaiser R, Mellemgaard A, Douillard JY, Orlov S, Krzakowski M, von Pawel J, Gottfried M, Bondarenko I, Liao M, Gann CN, Barrueco J, Gaschler-Markefski B, Novello S (2014) Docetaxel plus nintedanib versus docetaxel plus placebo in patients with previously treated non-small-cell lung cancer (LUME-Lung 1): a phase 3, double-blind, randomised controlled trial. Lancet Oncol 15: 143-155.

Rosell R, Carcereny E, Gervais R, Vergnenegre A, Massuti B, Felip E, Palmero R, Garcia-Gomez R, Pallares C, Sanchez JM, Porta R, Cobo M, Garrido P, Longo F, Moran T, Insa A, De Marinis F, Corre R, Bover I, Illiano A, Dansin E, de Castro J, Milella M, Reguart N, Altavilla G, Jimenez U, Provencio M, Moreno MA, Terrasa J, Munoz-Langa J, Valdivia J, Isla D, Domine M, Molinier O, Mazieres J, Baize N, Garcia-Campelo R, Robinet G, Rodriguez-Abreu D, Lopez-Vivanco G, Gebbia V, Ferrera-Delgado L, Bombaron P, Bernabe R, Bearz A, Artal A, Cortesi E, Rolfo C, SanchezRonco M, Drozdowskyj A, Queralt C, de Aguirre I, Ramirez JL, Sanchez JJ, Molina MA, Taron M, Paz-Ares L (2012) Erlotinib versus standard chemotherapy as first-line treatment for European patients with advanced EGFR mutation-positive non-small-cell lung cancer (EURTAC): a multicentre, open-label, randomised phase 3 trial. Lancet Oncol 13: 239-246.

Shaw AT, Ou SH, Bang YJ, Camidge DR, Solomon BJ, Salgia R, Riely GJ, Varella-Garcia M, Shapiro GI, Costa DB, Doebele RC, Le LP, Zheng Z, Tan W, Stephenson P, Shreeve SM, Tye LM, Christensen JG, Wilner KD, Clark JW, Iafrate AJ (2014) Crizotinib in ROS1-rearranged non-small-cell lung cancer. N Engl J Med 371: 1963-1971.

Shepherd FA, Dancey J, Ramlau R, Mattson K, Gralla R, O’Rourke M, Levitan N, Gressot L, Vincent M, Burkes R, Coughlin S, Kim Y, Berille J (2000) Prospective randomized trial of docetaxel versus best supportive care in patients with non-small-cell lung cancer previously treated with platinumbased chemotherapy. J Clin Oncol 18: 2095-2103.

Shepherd FA, Rodrigues Pereira J, Ciuleanu T, Tan EH, Hirsh V, Thongprasert S, Campos D, Maoleekoonpiroj S, Smylie M, Martins R, van Kooten M, Dediu M, Findlay B, Tu D, Johnston D, Bezjak A, Clark G, Santabarbara P, Seymour L (2005) Erlotinib in previously treated nonsmall-cell lung cancer. N Engl J Med 353: 123-132.

Siegel RL, Miller KD, Jemal A (2015) Cancer statistics, 2015. CA Cancer J Clin 65: 5-29.

Solomon BJ, Mok T, Kim DW, Wu YL, Nakagawa K, Mekhail T, Felip E, Cappuzzo F, Paolini J, Usari T, Iyer S, Reisman A, Wilner KD, Tursi J, Blackhall F (2014) First-line crizotinib versus chemotherapy in ALKpositive lung cancer. $N$ Engl J Med 371: 2167-2177.

Vrignaud P, Semiond D, Lejeune P, Bouchard H, Calvet L, Combeau C, Riou JF, Commercon A, Lavelle F, Bissery MC (2013) Preclinical antitumor activity of cabazitaxel, a semisynthetic taxane active in taxaneresistant tumors. Clin Cancer Res 19: 2973-2983.

Yang JC, Wu YL, Schuler M, Sebastian M, Popat S, Yamamoto N, Zhou C, Hu CP, O’Byrne K, Feng J, Lu S, Huang Y, Geater SL, Lee KY, Tsai CM, Gorbunova V, Hirsh V, Bennouna J, Orlov S, Mok T, Boyer M, Su WC, Lee KH, Kato T, Massey D, Shahidi M, Zazulina V, Sequist LV (2015) Afatinib versus cisplatin-based chemotherapy for EGFR mutation-positive lung adenocarcinoma (LUX-Lung 3 and LUX-Lung 6): analysis of overall survival data from two randomised, phase 3 trials. Lancet Oncol 16: 141-151.

This work is published under the standard license to publish agreement. After 12 months the work will become freely available and the license terms will switch to a Creative Commons AttributionNonCommercial-Share Alike 4.0 Unported License. 